\title{
HALLYU AND THE TRADITIONAL CULTURAL GENES OF KOREA
}

\author{
Ki-Duk Kim \\ Konkuk University \\ neutro@konkuk.ac.kr \\ First Author \\ Sang-Joon Bae \\ Konkuk University \\ sjbae@konkuk.ac.kr \\ Corresponding Author
}

\begin{abstract}
Since the year 200o, South Korea has been the propagator of the Hallyu (Korean Wave) that has spread across the world, demonstrating the country's cultural potential. The subject of Hallyu can be approached from several perspectives, first by identifying its origins, current status, and trends by genre; by looking at its effects and the measures that can sustain the Hallyu phenomenon; and also by examining Hallyu trends by country. This paper analyzes Korea's traditional cultural genes that affected the creation and spread of Hallyu from a humanistic point of view. The three factors for this analysis are: i) community and courtesy, ii) dynamics and excitement, and iii) intuition and harmony. This study is expected to deepen the understanding of the relation between Hallyu and Korean traditional cultural resources.
\end{abstract}

\section{Keywords}

Community, Courtesy, Cultural Gene, Dynamics, Excitement, Hallyu, Harmony, Intuition, K-pop 


\section{About the Authors}

Ki-duk Kim received his Ph.D. in History from Konkuk University in Seoul, Korea, where he is currently a Professor in the Department of Culture and Contents. He has been engaged in numerous studies on Visual History, Traditional Culture and Hallyu, and Contents planning.

Sang-Joon Bae earned his Ph.D. in Media Science at Philipps University Marburg, Germany and is currently a Professor in the Department of Culture and Contents at Konkuk University in Seoul, Korea. He recently published articles in Korean and European Film Contents and Film Theories. 


\section{INTRODUCTION}

Since the year 2000, the Hallyu phenomenon has demonstrated Korea's outstanding cultural potential worldwide. According to a recent survey, the total exports of the Hallyu industry amounted to 5.66 billion dollars (Korea Creative Content Agency 71). ${ }^{1}$ Hallyu, or the pop culture products created by South Korea, are going well beyond Asia to reach the world. Beyond entertainment-oriented programs, such as TV dramas, movies and K-pop, Hallyu expands to lifestyle culture based on Korea's food culture. It is remarkable that Hallyu has exerted such a strong influence on the global culture arena in the last two decades.

In response to this phenomenon, academic research on the characteristics and development of Hallyu is also actively underway. The existing research primarily concentrates upon identifying the causes, current statuses, and trends of Hallyu genres; the effects and measures that can sustain Hallyu as a phenomenon; and on particular manifestations of Hallyu trends in each country. A representative example of this research perspective is the approach based on "cultural hybridization." The thesis of cultural hybridization argues that Hallyu is not derived from Korea itself, but converged with other cultures. More precisely, the concept of cultural hybridity asserts that Hallyu is a crossbreed-output of cultural productions and consumptions of neighboring Asian countries that share similar cultural and historical backgrounds.

For example, Chua Beng Huat, who studies Singapore as the result of cultural hybridization from a postcolonial perspective, regards Korea as a multicultural, postcolonial nation and seeks in this perspective concrete relevance to Korean popular culture. In the same vein, $\mathrm{He}$ and Koichi Iwabuchi has explored how East Asian media cultures have made connections that cross national boundaries. According to them, Hallyu is closely connected with the historical relationship with Japan and other East Asian nations (Chua and Koichi). In relation to American-centrism, Shim Doobo addressed the hybridity of Hallyu by taking the position that the US dominance thesis is not entirely justified, but Koreans have provided their own media by blending indigenous characteristics that incorporates unique, indigenous styles. Jin Dal Yong accounts for Hallyu based on the cultural hybridity as well, especially Korean films and K-pop. He explains the hybridization process in Korean local culture is rather representing Western norms and formats, instead of unique local culture. Recently, Crystal S. Anderson refers to African-American Music tradition and aesthetics as having affected K-pop, such as found in the cases of Psy or Big Mama, who have both achieved unprecedented reputations in the world in recent years. In this analysis, she makes a statement about the cultural hybridity of R\&B and K-pop in Hallyu. 
Such cultural hybriditists argue that Hallyu is not autochthonic itself. Their opinion is that Hallyu is not due to Korean culture, rather other cultures or world events have influenced to the formalization of it. If so, from the perspective of cultural hybridity, the researchers cannot but ask why cultural phenomena like Hallyu have not been discovered in other East Asia nations. If Hallyu had spread across the globe due mainly to cultural hybridization, other phenomena similar to Hallyu should also appear on the scene. The aim of this paper is to examine traditional cultural genes as one of the possible answers to that question because traditional cultural genes lay the cornerstone of hybridization before cultures of neighboring countries are converged. Stated another way, the archetype of Hallyu is that of Korean traditional cultural genes. Other scholars argue otherwise and refuse to connect K-pop with aspects of traditional Korean culture-especially as found in the exaggerated importance given to sociocultural elements such as Confucianism (Lie). However, this paper takes a contrary research viewpoint by attempting to corroborate that cultural genes do contribute to the production of Hallyu.

In addition, approaches based on cultural hybridity have difficulty explaining the question of which traditional cultural elements affect the creation of Hallyu, and as a result, neglect the humanistic analysis of Hallyu contents. Thus, this paper attempts a humanities approach as the starting point for an analysis of Hallyu contents, which emphasizes the connection between tradition and modern.

To be sure, there are humanities-based studies which analyze Hallyu content. For example, Park So Young focuses on the transnational adoptee narrative in TV show and films in Hallyu. She points out that these stories contribute to changing the way Korean culture perceives itself and is perceived in the transnational imaginary. One other report suggests the storytelling strategy based on cultural glocalization. According to this report, the "feminine narrative" that can represent Hallyu content is able to interact with traditional narratives of China, France, the United States, and Indonesia (Oh et al.). However, although these studies focus on narrative analysis of some of the Korean traditional folklore, they take no notice of tracing the traditional cultural genes of Korean Confucianism contained in the various content of Hallyu. Thus, this paper aims to identify the traditional cultural genes that affected the creation of Hallyu and analyze its contents from a humanities-based viewpoint.

The concept of the "Korean cultural gene" used in this paper was derived from the process of contemplating the traditional continuity of Hallyu. ${ }^{2}$ Culture has elements of temporal continuity that consistently continue as cultures transform into various shapes from the past to the present, are possessed of elements of 
spatial differentiation that distinguish it from the cultures of other regions, along with elements of social commonality that can be identified in various cultural areas transcending specific fields or genres. These factors can be regarded as cultural genes as they have the cultural properties of acquiring, imitating, and transforming by being intertwined (Ko et al 6).

Therefore, this paper aims to analyze the source of Hallyu focused on three cultural genes of i) community and courtesy, ii) dynamics and excitement, and iii) intuition and harmony. Understandably, this study does not intend to demonstrate any notion of a putative cultural superiority inherent to South Korea. A characteristic can be a huge disadvantage when it works negatively. As will be summarized in the conclusion, the elements of cultural genes always have ambivalence, with positive and negative sides. Surely, such negative cultural genes may also influence Hallyu. By considering such ambivalence, this paper intends to identify the traditional cultural genes of Korea that affected Hallyu in a way that has influenced its current condition.

\section{THE CULTURAL GENES OF COMMUNITY AND COURTESY}

After five trips to Japan from 1977 to 1988, Claude Lévi-Strauss defined the East as centripetal and the West as centrifugal. Although he used only several examples, including the ways in which language is used and how a saw or a plane is handled, he expressed this concept by comparing the differences of the East and the West in a straightforward and clear manner. Richard E. Nisbett suggested different outlooks on the worlds of the East and the West based on various cases (120-147). His points accurately corresponded to the views of Lévi-Strauss. Nisbett made various comparisonsanddescribed thedifferencesbetween thetwo. Hisobservationsincluded the assertion that the East takes everything as a whole while the West focuses on parts rather than the whole; the East pieces everything together while the West analyzes everything; and the East compromises on issues while the West argues over them.

These thought ways reveal in the custom of language upon each cultural base. The West has a centrifugal way of thinking that views the world from the locus point of "me," the subject, and moves outwards. On the contrary, the East has a centripetal way of thinking that starts from the situation of the object and returns to "me," the subject. For example, the address systems of East and West are completely opposite. In the East, the address starts from the country name and ends with the house number. ${ }^{3}$ The same applies to people's names. The surname, which is one's 
family name, comes first and the first name, which is one's own name, comes the last. $^{4}$

These opposing situations of the self-reflect the communal characteristics of the East. Of course, even within the East practices vary by country. Korea maintains a relatively homogeneous racial composition in a single area of peninsula. Moreover, Korea traditionally maintained an agricultural society in ancient times, except during the Goguryeo period (37-668 BC). These factors are assumed to be the reasons why Korea is affected more strongly by communal factors.

Korea clearly demonstrates this Asian way of thinking in which people consider the whole first, starting from the object and coming back to "me," the subject, later. In a commonly mentioned language custom, Koreans use 'we' rather than 'I' as an idiomatic expression, which directly demonstrates this tendency. ${ }^{5}$ These communal characteristics are reflected in Korean TV dramas, movies and even K-pop. It is important to live in harmony with members of the community, as Koreans are used to communal ways of living. There is an old saying that "a cornerstone meets the mason's chisel." These words are etched into the collective cultural consciousness. It means that standing out is taboo. This is why historically Korean students have not been familiar with the teaching method of questions and discussions, and why the rote memorization-focused cramming method of teaching has dominated until recently.

The communal way of thinking emphasizes "courtesy." K-pop idol group members are required to have a training period that can last up to ten years. In this unique process of communal training, the K-pop trainees are under an obligation to take courtesy education. The trainees are required to say hello to others first in a polite manner at all times before practicing singing. This is a way to indoctrinate the trainees with courtesy before they sing a song. In Korea, courtesy is always the key factor in assessing a person. At the center of courtesy, there is a concept related to filial piety. In practice, Korean TV dramas and movies directly and indirectly reflect such social expressions of courtesy and notions of filial piety.

The following quotation is a part of the Chinese appreciation of Korean TV dramas. The viewers are especially impressed by courtesy, filial piety and family love in the contents.

Korean TV dramas are popularly broadcast. Chinese scholars and experts simply summarize the profound and penetrating argument for their popularity: cultural 
inheritance, vivid details, rich emotion, the promotion of filial piety. These are consistent with the essence of our Chinese traditional culture (Chén 96-97).

Korean TV dramas develop stories focusing on "Universal affectivity"; that is, family love, affection and friendship. In tranquil stories describing everyday life without much conflict, Universal affectivity gives warmth to the viewers. In addition, Korean TV dramas portray sophisticated scenarios but contain traditional family-oriented thoughts, filling the gap of what has already lost in Chinese society (Xú 34-35).

Elements such as a large family, filial piety and universal affectivity are very often mentioned in surveys about Korean TV dramas in other countries. To be sure, there must certainly be other reasons why Hallyu fans in China prefer Korean TV dramas. For example, independent female characters wear trendy fashion and fancy make-up, which links to K-beauty. However, filial piety and universal affectivity are most noticeable characteristics of the Chinese recognition of Hallyu. Above all, Korean TV dramas significantly feature the extensive family networks of the characters around the protagonists. Not only parents and grandparents, but also aunts or uncles often appear in the episodes. Although not all of them may live under the same roof, they often intervene in major issues of the main characters, such as marriage. In some cases, a marriage may be prevented due to family opposition, which can be hard to understand from a Western perspective.

Filial piety is one of the strongest ingrained elements in Korean TV dramas. It is filial piety that is one of the biggest characteristics of the general culture and family culture of Korea (Shin and Jang 145-146). However, it would be wrong to simply interpret the filial piety of Korea as an influence or remnant of Confucian culture, or the premodern age of Korean families, or as a distinct characteristic from a world historical point of view. Although Confucian culture emphasized filial piety and Korean society has been greatly influenced a lot by Confucianism, it is necessary to recognize that Korean filial piety contains world-historical universality that enriches humanity. In relation to this, the researchers suggest the following examples that imply the universal concept $:^{5}$

- History: Past - Present - Future

- Tree: Root - Trunk - Fruit

- Human: Parent - I - Child

As suggested above, past-present-future are inseparable. Root-trunk-fruit are inseparable for trees. Parent-I-child are inseparable as well, in human relations. The comparison of trees and humans was already emphasized in Confucianism, but the above perception is a universal message that goes beyond a certain 
ideology. People may prefer future, fruit and child, which are at the end of each diagram. But why is the history of the past important? This is because the past defines the present and determines the future. In addition, the fruits that are delicious and look beautiful will die if the roots are dead, either. Like this, the root is important in humans, too. Since loving children is based on human nature, it is practiced in most cases without the need for an artificial emphasis. But since filial piety towards parents is a natural duty with very strong social aspects, it is hardly found in practice without an accompanying societal emphasis in terms of education and norms (Shin and Jang 146). Just as people forget their history, or do not think of the roots of trees, all religious lessons include a commandment to "love your parents," but no commandment to "love your children."

In both the East and West, family is the beginning and end of humanity, as a value with timelessness, completeness, and constancy (Kwon 14). However, the world is faced with the global issue of family dissolution, and Korean society is experiencing the shrinking and breakdown of the family. Individuals are in an ambivalent situation in which the last "place to rest" should be family that they can rely on, despite the direction of recent trends (Kim 5-6). At this point, the researchers believe that while many solutions and measures have been proposed, it is most critical to restore and reconfirm the universal values of the culture of filial piety. The culture around the family and filial piety are reinterpreted in various forms and feature strongly in Korean TV dramas. Global viewers find the communal factors, courtesy and filial piety in Korean TV dramas to be somewhat extraordinary. ${ }^{6}$ For examples, one can refer to Daejangguem [Jewel in the Palace], Sangsokjaduel [The Inheritors], Nae ddal seoyoungi [My Daugther Seo-Young] and Sekeulit gaedeun [Secret Garden] etc.

Korean TV programs feature many talk shows focused on young K-pop stars. Watching these shows, one can see that many stars are often close to tears as they talk about filial piety towards their parents. No matter how many generations pass, there are communal factors, courtesy, and the culture of filial duty in the cultural genes of Koreans.

Based on a communal way of thinking, courtesy has been externally emphasized while strong affectivity has been internally established. Jeong is a very difficult word to translate. Love, affection and pity are similar words but do not express it perfectly. This word has a profound and mysterious signification, more exactly, it is a strong bond that includes hatred, jealousy, and resentment beyond love. In this paper, it is translated into "Universal affectivity." The members of a community need to have Universal affectivity to be complete as humans. No matter how competent a person is, the person is no good if he/she does not have Universal affectivity. 
If a cool-headed character does not have affectivity, the character cannot be the protagonist in Korean TV dramas and movies. In the storytelling of dramas and movies, the affective element of the main characters must be the key focus. Only then can everyone focus on the main characters.

Korean TV dramas, movies and even K-pop songs are deeply permeated by this universal human affectivity. Watching Korean media, Audiences from different context soon feel human affectivity. The task the world faces is to restore a sense of community, in which we are together rather than alone. That does not necessarily mean that we need to live together. The universal affectivity to pay attention and be considerate to others in human relations is the most vital task in this age. This is the reason why people are focusing on the universal affectivity in Hallyu products. For example, in China the one-child policy has been implemented for a long time. In addition, due to its rapid modernization, parents, children and relatives have become scattered throughout the whole county. As a result, the Spring Festival, in which families and relatives gather, has emerged as a significant national event. In this situation, the Hallyu TV drama, which contains community culture and universal affectivity, resonates strongly with the Chinese people.

This community, courtesy, and the culture of Universal affectivity seem to be closely related to agricultural society. In particular, the fact that group work was essential to rice farming is significant. Korea is one of the representative rice farming societies. The village unit in agricultural communities is a forum in which people share courtesy and Universal affectivity under a strong bond that is based on a sense of community. While agricultural communities and the communal characteristics may be seen in other countries, ${ }^{7}$ those factors in Korea often transcend gain and loss and interest because the affectivity of attention and consideration to others has traditionally been strongly established. This defines the courtesy and affectivity of Koreans.

\section{THE CULTURAL GENES OF DYNAMICS AND EXCITEMENT}

K-pop is about performance. Viewers can have fun listening, watching, and participating in it. K-pop performances are filled with the cultural genes of dynamicism and excitement, as they show flamboyant dances and visual images

of K-pop groups, while providing high quality music in various genres that communicate with audiences.

Let us discuss dynamicism first. Dynamicism expresses strong energy, based on the premise of high speed. This is where the representative expression of the 
"hurry up" nature of Koreans came from. Most consider the "hurry up" nature of Koreans as something that only became prominent in the $2 \mathrm{O}^{\text {th }}$ century. This might have been due to the fact that Koreans, who knew their nation was behind others, wanted to catch up with advanced countries in a short time through the process of modernization. However, we also need to focus on the wild nature and dynamicism of equestrian people in ancient times. As is well illustrated in the hunting pictures ${ }^{8}$ of Goguryeo in ancient times, hunting with an arrow on horseback was part of everyday life for people in Goguryeo. However, dynamicism should be on the premise of high speed. Of the representative sports in Goryeo (918-1392), gyeokgu is also always on horseback based on high speed. Gyeokgu is a game played on horseback with a ball and racquet. It was originally a game played by horse-riding people such as the Mongols, Siberians, and Turks. After gyeokgu was introduced in Korea, it became the national sport in the Goryeo Dynasty and a required subject of martial arts practice in the Joseon Dynasty (1392-1910). This means that gyeokgu, a game with a high-speed, dynamic nature, is suitable for Koreans. In other words, as the gene of dynamicism is based on the premise of high speed, the 'hurry up' nature of Koreans, which has been noticeable since modern times, is not unprecedented. ${ }^{9}$

It is thought that such dynamics and high speed were changed in the Joseon Dynasty where the culture of the virtuous scholars known as Seonbi unfolded based on culture of courtesy found in Confucianism. The attitude of Joseon scholars towards the world and nature had a relaxed nature to a large extent. The aspect of being relaxed in nature is also a cultural gene of Koreans. This characteristic transformed into a more distinctive phenomenon when Neo-Confucianism became the dominant religion in the Joseon Dynasty. This is why hurry up nature, dynamicism, and the natural and relaxed nature became the cultural genes of Koreans. ${ }^{10}$ While the aspect of dynamicism was prevalent before the Joseon Dynasty, the relaxed nature became stronger in the Joseon Dynasty. Since economic development in modern times, particularly in the 1960s, the "hurry up" nature has been prevalent, which is the premise of dynamicism. In other words, it is arguable that the hurry up sentiment and nature were generalized across society to meet the goal of compressed development during the process of modernization. It is thought that such characteristics emerge in an overall social system where people can survive if they can handle the process more quickly to meet survival conditions by reducing length of time for construction as well as for product manufacturing.

When dynamicism increases, people get excited. Excitement is an emotional state in which positive emotions such as impression and pleasure are elevated (Shin). But technologies are needed to bring dynamicism to a stage of excitement on the premise of high speed. Commonly, the cheering culture of Korea and K-pop uses repeated chants or songs. For example, there is a strong tendency to repeat short choruses, or hooks, in popular K-pop songs. Since 'Tell Me' by Wonder Girls 
(released in 2007), which gained popularity with the lyrics of "Tell me tell me tete-te-te-te-tell me," almost all songs by popular girl groups have a hook. This can be considered as a preliminary step to provoke excitement with repetitive rhythms. While it is discovered in K-pop, Koreans have their own way to enter a state of excitement. From the Korean cheering culture that was demonstrated to the world in 2002 World Cup in Seoul, to the cheering culture seen at festivals in baseball stadiums to civil demonstrations such as candlelight vigils, Koreans always make every event a festival venue by entering a state of excitement through repetitive chants and songs.

As this sentiment of excitement continues, people enter a stage of "sinmyeong" (exhilaration). This is a state of ecstasy or heightened excitement that reaches the level of contact with the Gods. Sinmyeong originally means the state in which a shaman is possessed by the Gods after contact with them. However, Koreans commonly express a heightened excitement as being exhilarated. This means that Koreans have many excitement factors. Of course, the element of sinmyeong is a universal phenomenon all over the world (Bourguignon). But the reason for emphasizing this element for Korea is that it is currently in progress and happens very frequently in everyday life.

In shamanism, once a shaman enters a stage of sinmyeong to contact the Gods, the excited shaman leads the field of exorcism. This is commonly found everywhere people attempt to make contact with the Gods. Africans often keep playing drums to contact the Gods. They repeatedly play drums slowly and quietly, and gradually their playing becomes quicker and stronger. This is how they release excitement in the stage of contacting the Gods via the preliminary stage of repeated drum playing (Rouget 136-137, 181). Koreans, however, by singing or listening to music very naturally or cheering together, routinely repeat the phenomenon of entering into the state of sinmyeong even today.

The K-pop of Hallyu has absorbed the American genres of electronic dance, $R \& B$, and hip hop and reinterpreted them from Korean perspectives. However, K-pop contributed to stimulate the self-development of a traditional Korean excitement, a culture of exhilaration, and the process of adding excitement as a preliminary stage of exhilaration. This is what makes people around the world enthusiastic about the songs despite the Korean-style lyrics. Lyrics are not important in the process of entering stages of excitement and exhilaration. The rhythm already leads to a state of excitement and exhilaration. Moreover, when entering the world of excitement and exhilaration, dance combines with songs to elevate excitement to the highest level. People experience a state of healing by singing along and dancing as they enter the world of excitement by listening to and watching the songs. 
More excitement is released when we are with other people rather than alone. This is why excitement is expressed in Korean society, where people are comfortable with a communal culture. There are no qualifications to participate in the sentiment of excitement, and no one is alienated. It is all right to not know the lyrics of the music. It is only necessary to remember some of the hook phrases. People get excited while singing along with the phrases. This is similar to chuimsae (exclamation) in traditional Pansori performances ${ }^{11}$ and the open-air stage for traditional masked dance performances in Korea, which are based on the tradition of audience participation. K-pop unites the audiences with sensuous rhythms, catchy lyrics, and fascinating dances. Additionally, the audiences respond actively by participating in the performances through singing and dancing along with the lyrics. The participants become 'one' and achieve unity. Language is not an important issue here. This is the beauty of deriving universal inspiration and healing that goes beyond the language barrier.

We live in an age of digital technologies. Korea's cultural genes of dynamicism and excitement are well suited to digital technologies. This is because the sentiment of high speed and improvisation is appropriate for the speed of digital media. The generation raised with smartphones pursues a faster speed than other generations. The speed of smartphones, which offer mobility and multifunctionality, is accelerating. Moreover, the narratives of exhilaration, rooted in traditional performances such as masked dance or Pansori, are in line with the narrative of the oral era. Due to the development of interactive digital technologies, communication is possessed of more verbally descriptive characteristics, as if two people are talking. Comments on the internet are closer to the field of speaking rather than writing. As such, the narratives of mass media have a lot in common with the narrative of orality rather than the narrative of the literacy culture era. The narratives of exhilaration rooted in the oral tradition are frequently observed in the mass media of the digital age (Yoon 331-340).

Before summarizing the cultural genes of dynamics and excitement on the premise of high speed, the researchers would like to discuss artisans (jangin) and masters (dalin). Many masters have been introduced in modern Korean society. There is a popular TV program that introduces masters in Korea. ${ }^{12}$ Artisans and masters are both skilled, but there are some differences between them. Artisans are experts who inherited a certain area of traditional culture over generations. Masters are limited to themselves and mostly skilled in the daily life. One of the remarkable characteristics of masters is high speed. Masters are surprisingly fast and accurate in their specialized areas. In the traditional era, Korea had a lot of artisans. But due to the difficult social situation with the decline of the Joseon Dynasty during the $19^{\text {th }}$ century and the colonialism of the $2 \mathrm{O}^{\text {th }}$ century, war, and national division, Korea failed to maintain its artisans. Because of this historical 
reality, there is a significantly lower number of artisans in modern Korea than Japan, and the tradition of artisans has diminished. Instead, modern Korea has a lot of masters. Masters are agile and their repeated agile actions cause dynamicism, which furthermore provokes the excitement of viewers. The highest masters are like possessed shamans. The researchers believe that such masters best show the cultural genes of dynamics and excitement.

\section{THE CULTURAL GENES OF INTUITION AND HARMONY}

Koreans are very familiar with the idea of generating harmony through intuition. This is well shown in Korean TV dramas and K-pop. The term 'harmony' does not mean getting along well with others in human relations. Rather, it means the state that forms a state of balance and beauty between several elements in proper combination. But Koreans use intuitive methods rather than analytical one to create a state of harmony. In this sense, this section is titled "The Cultural Genes of Intuition and Harmony."

As mentioned above, Levi-Strauss compared the characteristics of the East and the West based on languages. Western languages have centrifugal characteristics that move outwards from the inside of 'me.' Therefore, the subject, which is the main element in language, goes first in sentences, and in principle will never be omitted. However, in oriental languages, the subject does not have to come first. The way of putting the subject at the end of the sentence after describing the object first can be considered to be rather sophisticated (Lévi-Strauss 55-86).

In the same context, the researchers suggest the following different expressions of Korean and English: "Baekdu Mountain" in Korean is "Mount Baekdu" in English. "Apple one" is "an apple," "coffee a cup" is "a cup of coffee," "10 number" is "No. 10," " 5 page" is "pg. 5 " and "six chapter" is "Chapter VI." There are numerous differences in word expression. What do the Korean and Asian expressions mean? English expresses analytically one by one by moving towards the object from "me," the subject. The same applies to idiom. For example, you find at first "a" and then it is a "cup" and there is "coffee" "in" the cup. This is the analytic method used in the English language. But in Korean, it is expressed as if we already know that it is a cup of coffee. This explains "coffee a cup." This example is such a Korean language habit. After all, Korean is a language that implies that we already know the name of the mountain, that it is an apple, that it is a cup of coffee, that the number is ten, that the page is five and that the chapter is five. In short, it is a form of expression based on intuitive thinking. 
Richard E. Nisbett, also mentioned above, suggests that the East has a holistic understanding of the world, focusing on the relations in the overall context. As a result, Asians have intuitive thinking to observe the objects in connectivity of the whole. Intuition refers to the action of direct perception of the objects without any medium, including judgment and deduction or the results of the action. And analysis refers to dividing complex objects depending on the elements or properties of the objects, or breaking down the material elements in chemical and physical methods. Most Asians have a more advanced intuitive ability, while westerners have a more developed analytical ability.

Of the Eastern countries, Koreans have a particularly outstanding intuitive ability. The researchers believe that Koreans have a stronger multitasking ability in comparison with people from China and Japan, even though they are located in the same area. Let us consider a few examples. A travel report on Korea by a Chinese envoy in ancient times described that Koreans enjoy eating, drinking, singing and dancing, and men and women gather together to enjoy singing and dancing (Lim 224). Foreigners' records often describe the unique factors that are different from their own. In fact, simultaneous eating, drinking, singing, and dancing can be regarded as demonstrative of a multitasking ability, which might have been novel to the Chinese people, in that Koreans perform multiple tasks at the same time. These factors can be strongly observed among modern Koreans. This is not always a positive but is a well demonstrated trait, as many Koreans enjoy singing and dancing in noraebang (Karaoke rooms) and even on sightseeing buses.

The same applies for the hanok (Korean traditional house) that is used for various purposes depending on the household items. After Koreans get up in the morning and put away the bedding, the bedroom turns into the living room where family members can gather. As they have breakfast in the room, the bedroom turns into the dining room. When they greet the guests by laying out sitting mats and setting a table with drinks and snacks, the room turns into the reception room. When they set up a desk for reading books after the guests leave, the room turns into a study. If they weave straw mats using tools or a saw, the room turns into a workroom. When they make the bed to sleep in the evening, the room turns back into the bedroom (Lim 235-240). This lifestyle is not due to a lack of space, but because of the characteristics of pursuing a multitasking approach.

In this way, Koreans show an ability to intuitively identify various factors based on multitasking and harmonizing various factors. There are ten UNESCO cultural heritages in South Korea. However, most of them did not have blueprints, and were established through intuition with the discerning eye of harmony. For architecture, natural stones were used as foundation stones to construct buildings. Using the technique of 'scribing', timber was fitted into 
the foundation stones as is, and sometimes crooked trees were used. Complex buildings such as lecture halls or temples were built on the natural environment and arrangement rather than being geometrically planned. The world heritage Changdeokgung Palace was designed based on the beauty of untouched naturalness and hidden subtleness, as if it was embraced by nature. This naturalness of Korean culture is also considered to be an intuition-based view of harmony.

Korea has a tradition of "mixing culture." Mixing is referred to in modern language as fusion. Samulnori (Korean traditional percussion quartet) in which the four folk percussion instruments of drum, janggu (double-handed drum), jing (gong) and kkwaenggwari (small gong) are played in harmony, and bibimbap (mixed rice with colorful vegetables and meats) amply demonstrate the essence of Korea's 'mixing' culture in food and music. What is interesting is that different materials, while being harmonized, do not lose their own individuality. Mixing pursues a harmony of difference rather than as an assimilation that erases it (Jeong 171).

In fact, it is not long ago that the chemical components and effects of the colors of each food ingredient were clearly identified clarified. Nevertheless, Korean dining, which traditionally used the concept of color therapy to a nearly perfect extent, is both natural and extremely scientific. Koreans already knew the influences of the colors of each wave on the body and soul (Joo 47-48).

This is also well-demonstrated in Korean TV dramas or K-pop. These are like a mixing (bibim) culture, in which all participants are harmonized but the individuality of each person still exists. Since the mixing culture has been traditionally developed, the culture permeates Korean TV dramas or music so that individuals can survive in harmony with others.

In this way, Koreans demonstrate an ability to intuitively identify various issues based on mixing and multitasking and their harmonization. This is contained in every single one of today's Hallyu products. This multitasking element has the potential to become an element of convergence in the digital age. Digital technologies are perfect for Koreans who have the high-speed cultural gene. As a result, South Korea is standing out in the automobile, semiconductor, and smart phone sectors based on digital technologies. Moreover, the combination of high speed and digital technologies is providing favorable conditions for Hallyu dramas or K-pop and the MICE (Meeting, Incentive trip, Convention, Exhibition and event) industry. 
Meanwhile, the harmonizing characteristics of Korea can be distinguished from the aesthetic sensitivity of China that emphasized symmetry, or the aesthetic tendency of Japan based on thorough and complete calculation. Korea produces a variety of forms of art that are based on its mountain topography, and demonstrates that a nearly complete eschewing of rules.

Let us discuss the cultural genes of harmony in detail. The harmonizing ability based on intuition can be seen as an East Asian characteristic, but there are differences between Korea and China or Japan. In the East, the concept of Archetypes, commonly known as the yin and yang theory, has been developed. The principle of yin and yang refers to the relation of "the power that is opposite against each other and at the same time perfects each other," while also being "the power that can enable a better understanding of each other due to the existence of each other." A balanced state of yin and yang is called moderation. Therefore, the morality of moderation is the most important norm of conduct in Confucianism.

However, it is in fact very hard for the two elements of yin and yang to be compatible. Therefore, basically, there is always a contradiction before finding a balance and harmony between yin and yang. The East intends to accept the contradictory arguments through compromise. The key to this way of thinking is to find the truth in both of the two contradictory arguments. This is why it is so natural in the East to make endless efforts to explore moderation between two extreme propositions. In the Oriental way of thinking, contradiction is only superficial and a hypothesis in which "A is true but B is not necessarily false, either." is deeply inherent. This is how the East can accept the teaching of Zen Buddhism that "the opposite of big truth is also true" (Nisbett 133-151).

\section{CONCLUSION}

This paper analyzed the traditional cultural genes of Korea that affected Hallyu by categorizing them into three broad factors of i) community and courtesy ii) dynamicism, and excitement and iii) intuition and harmony. There are many other cultural genes which are not completely independent but are converged in harmony. Among them are a sense of community included in intimacy and excitement, Universal affectivity in communities, harmony in affectivity, and the naturalness of harmony. The researchers considered the correlations among the cultural genes, and summarized them into three factors that directly affected Hallyu.

As mentioned above, the cultural genes have the dual characteristics of being positive and negative at the same time. For example, communal characteristics 
cause a lack of identity when seen from a negative perspective. An emphasis on courtesy can lead to formalism if the fundamentals lose their original meaning. The most humane Universal affectivity can be applied to school ties and regionalism. In this case, there will be side effects of not refusing private interest that may harm fairness.

In reality, modern Koreans are often suffering from the side effects of a sense of community, courtesy and Universal affectivity. Due to traditional values, they have often failed to speak their mind. That is why many Koreans suffer from hwabyeong (mental or emotional disorder as a result of repressed anger or stress). Hwabyeong is disease unique to Koreans, which is internationally recognized. In 1995, the American Psychiatric Association used the term hwabyeong as pronounced in Korean.

The negative side of the hurry up nature is impatience. Excitement based on dynamicism may be partial deviation developed without being conscious of others. This can cause a lot of stress, mental illness, and a sense of alienation to those who lag behind. Indeed, South Korea has the highest suicide rate among OECD countries. As this issue is being taken seriously, there is a strong movement to develop the cultural genes of naturalness and relaxation to restore the communitybased virtue. Seeking harmony based on intuition can be regarded as maximization of illogicality, rationalizing the half-hearted trend and non-planning. This will weaken competitiveness and provoke social polarization.

Therefore, no matter how beautiful and meaningful the cultural genes are, they are not always beautiful in themselves. These factors can be applied to the opposite side whenever they become extreme. Further studies should consider the negative examples of cultural genes, and related solutions. This study analyzed the traditional cultural genes of Korea that affected Hallyu. Therefore, the researchers had no choice but to pursue positive perspectives. Hallyu is based on Korea's own traditional cultural gene. However, the influence of Hallyu can be found in the healing of the mind and body of modern people. Therefore, Hallyu could be regarded as the implementation of a universal cultural mission that is needed by people of the world in this era.

Of course, every country in the world also has various cultural genes whose traditional elements continue to the present day. The Korean cultural genes of community and courtesy, dynamicism, and excitement, and intuition and harmony which are mentioned in this paper are also the same. However, Korea created the phenomenon of Hallyu by combining these elements with digital media and converging it into various cultural products. The researchers hope that this paper contributes to providing an in-depth understanding of the Korean culture so that 
people can more accurately understand Hallyu, and furthermore, contributes to cross-cultural perspectives. 


\section{Acknowledgement}

This work was supported by a National Research Foundation of Korea Grant, funded by the Korean Government (2014S1A3A2044638)

\section{Notes}

1. These are 2015 statistics, and can be used as a reference for the exports by industry and country. This sum ( 5.66 billion dollars) is a combination of direct exports (57.1\%) and indirect exports using agents (42.9\%), p.73, table 2-5-9.

2. To avoid misunderstandings, it is pointed out that 'cultural genes' is not linked with argument about biological genes by Richard Dawkins. (Richard Dawkins, 1976). 'Cultural genes', the expression used in this paper, can be understood as 'cultural resources. This concept of cultural genes started to be used in earnest in 2012 (Korean Studies Advancement Center, 2012).

3. An example: "(Republic of Korea) Seoul Jongno-gu 1 Daehan Building \#401" is translated into "\#401 Daehan Building 1 Jongno-gu Seoul Republic of Korea" in English.

4. An example: "Kim Ki duk" is translated into "Ki duk Kim" in English. The word "we" is most frequently used in Korean. Koreans say "our home" instead of "my home" and "our mom" instead of "my mom".

5. Comparisons between trees and humans are emphasized in Confucian scriptures. The researchers developed this logic including history (Kim Ki-duk 130).

6. One thing to add is that the family-oriented thoughts and filial duty contained in Hallyu dramas do not necessarily reflect the reality of South Korea in an accurate way. South Korea is already experiencing family dissolution and weakened filial piety. However, it is true that such elements still remain relatively strong in Korea. That is why such elements are contained in Hallyu dramas.

7. In medieval times, when agriculture was the main industry, the West was not that individualistic. At that time, the European farmers were not much different from Chinese farmers in their ways of thinking or social patterns of behavior (Nisbett.190-192).

8. The hunting pictures of Goguryeo remained in the form of the ancient tomb murals, which are registered as world cultural heritages by UNESCO. The tomb of members of the ruling class of Goguryeo was made like a room, and all sides of the room were decorated with paintings. The hunting picture mentioned in the text is one of them. These paintings are valuable, in that they show vivid images of life at that time. 
9. The farming life is a battle against time. This is particularly so in Korea, where there are four seasons. Farmers need to remember the perfect timing and be on time. Those who do not know the timing do not know the seasons. Farmers need to know the timing and work exactly on time. In the agricultural areas, there are busy farming seasons, which do not exist in nomadic culture. In the seedtime and harvest time, farmers get very busy. The characteristic of Koreans trying do everything quickly is somewhat related to the cultural genes of such agricultural people (Lim 25-235).

10. The 10 cultural genes of Koreans identified through the survey in 2012 are as follows: intimacy, Universal affectivity, naturalness, community, harmony, humor, excitement, courtesy, dynamics and perseverance.

11. Pansori was registered as Intangible Cultural Heritage by UNESCO in 2008.

12. For example, you can mention the TV program "Saenghwalui dalin" [A master of life] of SBS (Seoul Broadcasting System) and "dalin" section of "Gaegeukonseoteu" [Gag Concert] of KBS (Korean Broadcasting System). 


\section{Works Cited}

Anderson, Crystal S. "Hybrid Hallyu: The African American Music Tradition in K-Pop." Global Asian American Popular Cultures, NYU P, 2016, pp.290-303.

Bourguignon, Erika. "Introduction: A Framework for the Comparative Study of Altered States of Consciousness." Religion, Altered States of Consciousness and Social Change, edited by E. Bourguignon, Ohio State UP, 1973, pp.3-35.

-.. "Vienna and Memory: Anthropology and Experience." Ethos: Journal of the Society for Psychological Anthropology, vol. 24, no. 2, 1996, pp. 374-387.

Chén, Jing Lì. "hánjù de mèilì-tán hánjù jiātíng lúnlĩ jiàzhíguān duì zhōngguó shòuzhòng de y̌ngxiăng [The Influence of Korean family ethics on Chinese audiences]." shěnyáng dàxué xuébào [Journal of Shenyang University], vol. 5, 2008, pp. 96-97.

Chua, Beng Huat, and Koichi Iwabuchi. East Asian Pop Culture: Analyzing the Korean Wave. Hong Kong UP, 2008.

Chua, Beng Huat. "Conceptualizing an East Asian Popular Culture." Inter-Asia Cultural Studies, vol. 5, no. 2, 2004, pp. 200-221.

Dawkins, Richard. The Selfish Gene. Oxford UP, 1976.

Jeong, Hae-gyeong. "Bibim, yungtong, nanumeulo isneun eoullimui jihye." [The Wisdom of Harmony Made with Mixing, Flexibility, and Sharing]. The Cultural Genes of Koreans, Amor Mundi, 2012, pp. 171-181.

Jin, Dal Yong. "Critical Interpretation of Hybridization in Korean Cinema." Journal of European Institute for Communication and Culture, vol. 17, 2010, pp. 55-71.

Joo, Yeong-ha. "Balhyoeumsig, siganui sugseongeul tonghae jinjeonghan mase ileuda." [Fermented Food Reached the Real Taste After Aging]. The Cultural Genes of Koreans, Amor Mundi, 2012, pp. 20-39.

Kim, Gyeong-il. Geundaeui gajog, geundaeui gyeolhon. [Modern Family, Modern Marriage]. Blue History, 2012.

Kim, Ki-duk. "Hanlyu delamae natanan gajogjuui." [The Concept of Familism apparent in the so-called Korean-Wave TV Drama]. The Cultural Genes of Koreans, Amor Mundi, 2012, pp. 116-135.

Ko, Duhyun, et al. hangug munhwayujeonja jido [The map of Korean Cultural genes]. Story House, 2014.

Korea Creative Content Agency. "2016 Kontencheusaneob tonggyejosa” [A Statistical Survey on the Content Industry 2016], 2016.

Kwon, Myeong-a. Gajogiyagineun eotteohge mandeuleojineunga. [How Family Stories Are Created]. Book World, 2000.

Levi-Strauss, Claude. L'Autre face de lune. Editions du Seuil, 2011.

Lie, John. "What is the K in K-pop? South Korean Popular Music, the Culture Industry, and National Identity." Korea Observer, vol. 43, no. 3, 2012, pp. 339-363.

Lim, Jae-hae. "Seumateupongwa daejungmunhwa hyeonsangui munhwayujeonja insig" [Current Phenomena of Smartphone and Pop-culture and the Recognition of Memme]. Folklore of Namdo 27, 2013. 
Nisbett, Richard E. The Geography of Thought. Brockman, 2003.

Oh, Ingyu et al. Hallyu 3.o gwa munhwageullokeolhwaui inmunhagjeog yeongu

[Humanities Research on Hallyu 3.0 and Glocalizing Culture]. National Research Council for Economics Humanities and Social Science, 2014.

Park, Shin-hee. "Yeogdongseong, yeoljeonggwa huimangui ttodaleun ileum." [Dynamics, Another Name of Enthusiasm and Hope]. The Cultural Genes of Koreans, Amor Mundi, 2012, pp. 289-299.

Park, So Young. "Transnational Adoption, Hallyu, and the Politics of Korea Popular Culture." Biography, vol. 33 no. 1, U of Hawai'i P, 2010, pp. 151-166.

Rouget, Gilbert. Music and Trance. A Theory of the Relations between Music and Possession. U of Chicago P, 1985.

Shim, Doboo. "Hybridity and the Rise of Korean Popular Culture in Asia." Media, Culture E Society, vol. 28, No. 1, 2006, pp. 25-44.

Shin, Eun-kyeong. Punglyu dongasia mihagui geunwon. [The Source of Aesthetics in East Asia]. Bogosa, 1999.

Shin, Yong-ha, Jang Gyeong-seop. 21segi hangugui gajoggwa gongdongchemunhwa. [Family and Communal Culture of Korea in the $21^{\text {st }}$ Century]. Jisik Sanup Publication, 1996.

Xú, Péng. "hán liứ bù hán-duō jiăodù jiědú hánguó diànshìjù chénggōng de yuányīn." ["Korean Wave' is not cold - multi-angle interpretation of the success of Korean TV series"]. miányáng shĩfàn xuéyuàn xuébào [Journal of Mianyang Teachers College], vol. 1, 2007, pp. 34-35.

Yoon, Tae-il. "Sinmyeongui maecheseosahage daehan tamsaegjeog gochal." [Exploring the concept of Shinmyoung-based Media Narratology]. Journal of Communication Science, vol. 10, no. 4, 2010, pp. 307-349. 